\title{
PENGARUH INFORMASI NON KEUANGAN TERHADAP KEPUTUSAN INVESTASI DI BURSA EFEK INDONESIA
}

\section{EFFECT OF NON FINANCIAL INFORMATION ON INVESTMENT DECISIONS IN INDONESIA STOCK EXCHANGE}

\author{
Alisastra Dison Silalahi, Erlina \\ Universitas Sumatera Utara ${ }^{1,2}$ \\ Alisastra.disonsilalahi@gmail.com ${ }^{1}$
}

\begin{abstract}
Non-financial information describes the company's future performance, and at the same time illustrates that the company has been managed well. This research was conducted to see whether non-financial information influences investment decisions on the Indonesian stock exchange. The sample technique used in this study was purposive sampling with criteria: investors who started investing in 2015, investors who had a diploma and bachelor's education and investors who invested for three years. The analysis technique in this study is simple linear regression and moderated regression anlysis. Hypothesis testing in this study shows that non-financial information influences investment decisions.
\end{abstract}

Keywords: Non-Financial Information, Investment Decisions and Financial Advisory Recommendations

\begin{abstract}
ABSTRAK
Informasi non keuangan menggambarkan kinerja masa depan perusahaan, dan pada saat yang sama menggambarkan bahwa perusahaan telah di kelola dengan baik. Penelitian ini dilakukan untuk melihat apakah informasi non keuangan berpengaruh terhadap keputusan investasi di bursa efek Indonesia. Teknik sampel yang di gunakan dalam penelitian ini adalah purposive sampling denga kriteria yaitu investor yang mulai berinvestasi tahun 2015, investor yang memiliki pendidikan terakhir diploma dan sarjana dan investor yang berinvestasi selama tiga tahun. Teknik analisis dalam penelitian ini regresi linier sederhana dan moderasi moderated regression anlysis. Uji hipotesis pada penelitian ini menunjukkan bahwa informasi non keuangan berpengaruh terhadap keputusan investasi.
\end{abstract}

Kata Kunci: Informasi Non Keuangan, Keputusan Investasi dan Rekomendasi Penasihat Keuangan.

\section{PENDAHULUAN}

Informasi non keuangan

merupakan informasi di luar data keuangan perusahaan. Investor dapat memperoleh informasi non keuangan tersebut melalui prospektus yang di terbitkan oleh perusahaan. Pada penelitian ini, proxy untuk variable informasi non keuangan yaitu berupa citra perusahaan yang mana merupakan salah satu elemen yang mendukung para investor untuk melakukan investasi di pasar modal.

Dalam meningkatkan citra positif perusahaan dimata investor 
banyak perusahaan-perusahaan nasional maupun internasioanal melakukan CSR (corporate social responsibility), karena hal tersebut diyakini sebagai investasi yang akan menaikan kinerja jangka panjang perusahaan.

Banyak pihak yang mendukung peningkatan pengungkapan informasi non keuangan. Ikbal (2018) menyatakan bahwa sebagian pimpinan perusahaan maupun investor besar percaya bahwa informasi non keuangan dapat mengukur bobot atau kualitas sebuah informasi keuangan, istilahnya informasi non keuangan mampu membentuk nilai perusahaan dalam jangka panjang. Informasi non keuangan menggambarkan kinerja masa depan perusahaan, dan pada saat yang sama menggambarkan bahwa perusahaan telah di kelola dengan baik (Aniwaty 2016).

Para peneliti di dunia akademik dan berbagai lembaga non pemerintah telah menyerukan untuk memeriksa kembali dari informasi-informasi non keuangan dan memisahkannya dengan neraca perusahaan tapi menawarkan bukti material yang jelas bagaimana informasi non keuangan untuk pengambilan keputusan oleh para investor (Ratnasari \& Hudiwinarsih 2013). Di antaranya penelitian yang melakukan penelitian terkait informasi non keuangan terhadap keputusan investasi di antaranya Septyanto (2013) dan Ratnasari \& Hudiwinarsih (2013).

Dengan banyaknya investor yang melakukan investasi hanya berdasarkan informasi keuangan dalam upaya menilai kinerja perusahaan tanpa melihat informasi non keuangan perusahaan, meliputi Citra perusahaan. Seperti kasus Raihan Jawellery yang menawarkan kepada investor tentang imbal hasil sebesar 3-5 \% per bulan bagi investor yang menanamkan dana dan investasi emas. Imbal hasil rutin dibayarkan sejak tahun 2010, tetapi berhenti pada januari 2016. Dana nasabah yang di himpun di perkirakan mencapai 13,2 triliun untuk total 2,2 ton emas, (Kompas.com). Oleh karena banyak investor yang kurang percaya dalam menginvestasikan dananya dengan berkurangnya nilai relavansi laba yang ada dalam informasi keuangan.

Rekomendasi Penasihat Keuangan adalah salah satu informasi lainnya yang dapat mempengaruhi keputusan investasi individu. Rekomendasi penasehat keuangan terdiri dari broker, keluarga maupun teman. Dalam penelitian ini, rekomendasi dari para analis financial juga di golongkan dalam rekomendasi penasihat keuangan (Firmanah \& Muharam 2015).

Citra perusahaan dan kinerja saham merupakan faktor yang penting untuk memahami perilaku dan sikap investor. Di dalam berinvestasi di perlukan partisipan yang akan mempengaruhi rekomendasi dalam menganalisis dan menilai suatu investasi yang potensial ketika saham tersebut berada dalam rekomendasi beli dibandingkan jual, seperti teman, keluarga, broker dan lain-lain (Ikbal 2018).

Informasi non keuangan merupakan informasi diluar data keuangan perusahaan. Investor dapat memperoleh informasi non keuanagan tersebut melalui prospektus yang diterbitkan oleh perusahaan. Informasi non keuangan yang ditawarkan pada prospektus yaitu seperti banyaknya lembar saham yang ditawarkan dan harga saham yang ditawarkan, tujuan IPO, pengguna dana hasil IPO, resiko usaha, kegiatan dan prospek usaha, kebijakan dividen, penjamin emisi efek, profesi penunjang pasar modal, 
dan lain sebagainya. Pada penelitian ini, proxy untuk variabel informasi non keuangan yaitu berupa citra perusahaan. Citra perusahaan merupakan salah satu profesi penunjang pasar modal yang mendorong investasi untuk menanamkan modal di pasar modal. Informasi keuangan yaitu berupa informasi yang berasal dari data keuangan perusahaan seperti laporan keuangan perusahaan. Laporan keuangan merupakan data keuangan yang diorganisir secara logis dan dengan prosedur akuntansi yang konsisten.Laporan keuangan yang utama yaitu neraca, laporan laba-rugi dan perubahan modal dimana menunjukkan posisi keuangan, hasil kegiatan dan permodalan perusahaan untuk periode tertentu.

Salah satu informasi lainnya yang dapat mempengaruhi keputusan investasi individu adalah rekomendasi penasehat keuangan. Penasehat keuangan adalah pihak yang memberi nasihat kepada pihak lain mengenai penjualan atau pembelian efek, sedangkan. Penasihat investasi adalah perusahaan atau pihak yang memberikan nasihat kepada pihak lain mengenai penjualan atau pembelian efek dengan memperoleh imbalan atau jasa rekomendasi penasehat keuangan, terdiri dari rekomendasi broker, keluarga, maupun teman (Yaya et al., 2013).

Investasi merupakan penanaman dana yang dilakukan oleh suatu perusahaan kedalam suatu aset (aktiva) dengan harapan memperoleh pendapatan dimasa yang akan datang

Saham dapat didefinisikan sebagai tanda bukti penyertaan kepemilikan modal atau dana pada suatu perusahaan, kertas yang tercantum dengan jenis nilai nomilan, nama perusahaan, disertai dengan hak dan kewajiban yang dijelaskan kepada setiap pemegangnya, dan persediaan yang siap untuk dijual. Saham adalah surat bukti kepemilikan asset-asset perusahaan yang menerbitkan saham. Dengan memiliki saham suatu perusahaan, maka investor akan mempunyai hak terhadap pendapatan dan kekayaan perusahaan, setelah dikurangi dengan pembayaran kewajiban perusahaan.

\section{METODE PENELITIAN}

Jenis data yang digunakan dalam penelitian ini adalah data primer. Data yang diperoleh secara langsung melalui kuesioner yang diberikan kepada responden. Populasi pada penelitian ini sebanyak 30 perusahaan dengan jumlah sampel sebanyak 75 orang investor yang masih aktif dengan teknik sampel yang digunakan adalah Purposive Sampling yaitu dengan menentukan kriteria sebagai berikut:

1. Investor yang mulai berinvestasi pada tahun 2015.

2. Investor yang memiliki tingkat pendidikan terakhir diploma dan sarjana.

3. Investor yang berinvestasi selama 3 tahun.

Adapun teknik analisis data dalam penelitian ini menggunkan analisis regresi linier sederhana dan regresi MRA

\section{HASIL DAN PEMBAHASAN}

Hasil dari pengolahan data pada penelitian ini yaitu:

\section{Uji Validitas}

Hasil uji validitas masing-masing item pada variabel Informasi Non Keuangan, Rekomendasi Penasihat Keuangan, dan Keputusan Investasi di sajikan pada tabel sebagai berikut: 
Tabel 1 Hasil Uji Validitas Variabel Informasi Non Keuangan

\begin{tabular}{llllll}
\hline Item & $\mathrm{N}$ & $\mathrm{r}$ hitung & $\mathrm{r}$ Tabel & Sig & Ket \\
\hline P1 & 75 & 0,480 & 0,227 & 0,000 & Valid \\
\hline P2 & 75 & 0,626 & 0,227 & 0,000 & Valid \\
\hline P3 & 75 & 0,385 & 0,227 & 0,001 & Valid \\
\hline P4 & 75 & 0,549 & 0,227 & 0,000 & Valid \\
\hline P5 & 75 & 0,447 & 0,227 & 0,000 & Valid \\
\hline P6 & 75 & 0,306 & 0,227 & 0,008 & Valid \\
\hline
\end{tabular}

Sumber: Data diolah SPSS (2019)

Tabel 2 Hasil Uji Validitas Variabel Rekomendasi Penasihat Keuangan

\begin{tabular}{llllll}
\hline Item & $\mathrm{N}$ & r hitung & r Tabel & Sig & Ket \\
\hline P1 & 75 & 0,562 & 0,227 & 0,000 & Valid \\
\hline P2 & 75 & 0,432 & 0,227 & 0,000 & Valid \\
\hline P3 & 75 & 0,687 & 0,227 & 0,000 & Valid \\
\hline P4 & 75 & 0,533 & 0,227 & 0,000 & Valid \\
\hline P5 & 75 & 0,308 & 0,227 & 0,007 & Valid \\
\hline \multicolumn{5}{c}{ Sumber: Data diolah SPSS (2019) }
\end{tabular}

Tabel 3 Hasil Uji Validitas Variabel Keputusan Investasi

\begin{tabular}{llllll}
\hline Item & $\mathrm{N}$ & r hitung & r tabel & Sig. & Ket \\
\hline P1 & 75 & 0,339 & 0,227 & 0,003 & Valid \\
\hline P2 & 75 & 0,390 & 0,227 & 0,001 & Valid \\
\hline P3 & 75 & 0,431 & 0,227 & 0,000 & Valid \\
\hline P4 & 75 & 0,283 & 0,227 & 0,014 & Valid \\
\hline P5 & 75 & 0,294 & 0,227 & 0,095 & Valid \\
\hline P6 & 75 & 1,000 & 0,227 & 0,000 & Valid \\
\hline \multicolumn{5}{c}{ Sumber: Data diolah SPSS $(2019)$}
\end{tabular}

Berdasarkan tabel 1,2 dan 3 di atas dapat dilihat bahwa keseluruhan variabel yg digunakan dalam penelitian ini adalah valid sehingga dapat di lanjutkan ke analisa berikutnya.

\section{Uji Reliabilitas}

Hasil pengujian reliabilitas data dengan menggunakan metode AlphaCronbach terhadap variabel-variabel yang terdapat pada kuesioner di sajikan pada tabel sebagai berikut:
Tabel 4. Hasil Uji Reliabilitas

\begin{tabular}{lccl}
\hline Variabel & $\begin{array}{c}\text { Alpha- } \\
\text { Cronbach }\end{array}$ & t Tabel & Ket \\
\hline $\begin{array}{l}\text { Informasi } \\
\text { Keuangan (X) }\end{array}$ & Non 0,318 & 1,993 & Reliable \\
\hline $\begin{array}{l}\text { Rekomendasi } \\
\text { Penasehat }\end{array}$ & 0,291 & 1,993 & Reliable \\
Keuangan (Y) & & & \\
\hline $\begin{array}{l}\text { Keputusan } \\
\text { Investasi (M) }\end{array}$ & 0.418 & 1,993 & Reliable \\
\hline \multicolumn{1}{l}{ Sumber: Data diolah SPSS (2019) } &
\end{tabular}

\section{Uji Hipotesis}

Berdasarkan perhitungan diperoleh persamaan analisis regresi linier sederhana:

\section{$Y=26,134+0,155 X$}

Persamaan regresi yang dapat di interprestasikan konstanta sebesar 26,134 artinya apabila nilai informasi non keuangan di anggap bernilai 0 , maka kualitas laporan keuangan sebesar 26,134 dan Koefisien nilai informasi non keaungan $(\mathrm{X})$ sebesar 0,155 , artinya apabila nilai informasi non keuangan mengalami kenaikan sebesar satusatuan, kualitas laporan keuangan akan mengalami kenaikan sebesar 0,155. Sedangkan analisis regresi moderasi diperoleh persamaan:

\section{$Y=26,134+0,155+0,068+0,155 * 0,068$}

Persamaan regresi yang dapat di interprestasikan sebagai berikut:

1. Konstanta sebesar 26,134 artinya apabila nilai informasi non keuangan di anggap bernilai 0 , maka kualitas laporan keuangan sebesar 26.134 .

2. Koefisien nilai informasi non keuangan (X) sebesar 0,155 , artinya apabila nilai informasi non keuangan mengalami kenaikan sebesar satu-satuan, kualitas laporan keuangan akan mengalami kenaikan sebesar 0,155. 
3. Koefisien nilai rekomendasi penasihat keuangan $(\mathrm{M})$ sebesar 0,068, artinya apabila nilai keputusan investasi mengalami kenaikan sebesar satu-satuan, kualitas laporan keuangan akan mengalami kenaikan sebesar 0,068 .

4. Koefisien nilai informasi non keuangan dan rekomendasi penasihat keuangan sebesar 0,01054, artinya apabila nilai informasi non keuangan dengan keputusan investasi akan mengalami kenaikan sebesar 0,01054

Tabel 5 Hasil uji t

\begin{tabular}{lcc}
\hline Variabel & $\mathrm{T}$ & Sig \\
\hline Constant & 16.732 & 0.000 \\
\hline Inf. Non & 1.343 & 0.184 \\
Keuangan & & \\
\hline \multicolumn{2}{l}{$\begin{array}{l}\text { Sumber: Data diolah SPSS (2019) } \\
\text { Dari tabel uji }\end{array}$} \\
\multicolumn{2}{c}{ diatas }
\end{tabular}

diperoleh nilai $t_{\text {hitung }}<$ dari $t_{\text {tabel }}$, dengan nilai thitung sebesar 1,343 dan nilai $t_{\text {tabel }}$ sebesar 1,993. Hal ini menyatakan bahwa $\mathrm{H}_{0}$ di terima yang berarti bahwa Informasi Non Keuangan berpengaruh terhadap Keputusan Investasi. Sedangkan nilai $\mathrm{R}$ square di peroleh nilai 0,032 , yang berarti bahwa variabel bebas informasi non keuangan mempengaruhi variabel keputusan investasi sebesar $32 \%$ sedangkan sisanya yaitu sebesar $68 \%$ yang di pengaruh oleh faktor lain yang tidak diteliti dalam penelitian ini.

Hipotesis menunjukkan bahwa $\mathrm{H}_{0}$ diterima dan $\mathrm{H}_{\mathrm{a}}$ ditolak menunjukkan bahwa informasi non keuangan berpengaruh terhadap keputusan investasi, hal tersebut dapat dilihat dari hasil uji $t$ yang menunjukkan nilai $t_{\text {hitung }}<$ dari $t_{\text {tabel}}$, dengan nilai thitung sebesar 1,343 dan nilai $t_{\text {tabel }}$ sebesar 1,993. Hal ini menyatakan bahwa $\mathrm{H}_{0}$ di terima yang berarti bahwa Informasi Non Keuangan berpengaruh terhadap Keputusan Investasi. Sedangkan nilai $\mathrm{R}$ square di peroleh nilai 0,032 , yang berarti bahwa variabel bebas informasi non keuangan mempengaruhi variabel keputusan investasi sebesar $32 \%$ sedangkan sisanya yaitu sebesar 68\% yang di pengaruh oleh faktor lain yang tidak diteliti dalam penelitian ini. Hasil penelitian ini sejalah dengan penelitian yang dilakukan oleh Septyanto (2013) dan Ratnasari \& Hudiwinarsih (2013) dimana hasil penelitian menunjukkan bahwa informasi non keuangan berpengaruh terhadap keputusan investasi.

\section{PENUTUP}

\section{Kesimpulan}

Kesimpulan dari penelitian ini adalah untuk melihat pengaruh informasi non keuangan terhadap keputusan investasi di bursa efek Indonesia yaitu Pada uji $\mathrm{t}$ diperoleh nilai $t_{\text {hitung }}<$ dari $t_{\text {tabel }}$, dengan nilai $t_{\text {hitung }}$ sebesar 1,343 dan nilai $t_{\text {tabel }}$ sebesar 1,993. Hal ini menyatakan bahwa $\mathrm{H}_{0}$ di terima yang berarti bahwa Informasi Non Keuangan berpengaruh terhadap Keputusan Investasi. Sedangkan nilai $\mathrm{R}$ square di peroleh nilai 0,032 , yang berarti bahwa variabel bebas informasi non keuangan mempengaruhi variabel keputusan investasi sebesar $32 \%$ sedangkan sisanya yaitu sebesar $68 \%$ yang di pengaruh oleh faktor lain yang tidak diteliti dalam penelitian ini.

\section{Saran}

Adapun saran dalam penelitian ini adalah sebagai berikut :

1. Diharapkan penelitian selanjutnya dapat melakukan wawancara lansung kepada responden tidak 
hanya menggunakan data yang dari kuesioner saja.

2. Penelitian selanjutnya di harapkan menggunakan sampel lebih banyak, agar data yang di peroleh lebih akurat.

\section{DAFTAR PUSTAKA}

Aniwaty, A.,R. (2016). Pengaruh Informasi Keuangan dan Keuangan Terhadap Initial Return Pada Perusahaan Yang Melakukan IPO di Bursa Eefek Indonesia.

Firmanah, D. U., \& Muharam, H. (2015). Analisis Pengaruh Informasi Non Keuangan, Informasi Keuangan, dan Ownership Terhadap Underpricing Pada Perusahaan Non Keuangan yang Melakukan Initial Public Offering (IPO) di BEI Periode 20082014 (Doctoral dissertation, Fakultas Ekonomika dan Bisnis).

Ikbal, M. (2018). Apakah Informasi non-Keuangan berguna bagi Investor: Survei Persepsi bagi Investor Retail di Indonesia. AKUNTABEL, 14(2), 180-186.

Kompas.com. (2019). Pemilik raihan jewellery ditahan. Diakses pada 22 oktober 2019, dari http://sains.kompas .com/read/2013/04/17/0253086/ pemilik.raihan.jewellery.ditahan Ratnasari, A., \& Hudiwinarsih, G. (2013). Analisis Pengaruh Informasi Keuangan, Non Keuangan serta Ekonomi Makro terhadap Underpricing pada Perusahaan ketika IPO. Buletin Studi Ekonomi.
Septyanto, D. (2013). Faktor-Faktor yang Mempengaruhi Investor Individu dalam Pengambilan Keputusan Investasi Sekuritas di Bursa Efek Indonesia (BEI). Jurnal Ekonomi Universitas Esa Unggul,4(2), 17907.

Yaya, R., Abdurahim, A., \& Nugraha, D. A. (2015). Kesenjangan Harapan Antara Nasabah dan Manajemen terhadap Penyampaian Informasi Keuangan dan Non Keuangan Bank Syariah. Journal of Accounting and Investment, 8(1), 1-16. 